KAMILA KŁUDKIEWICZ

Uniwersytet im. Adama Mickiewicza w Poznaniu, Instytut Historii Sztuki

\title{
"Czarować chciała tylko powabem umysłu". O formacji intelektualnej Marianny z Ciecierskich Skórzewskiej na podstawie inwentarza jej księgozbioru
}

Streszczenie. Marianna z Ciecierskich Skórzewska (1741-1773), majętna szlachcianka, żona generała Franciszka Skórzewskiego dzieliła czas między Wielkopolskę (pałac generałostwa w Margonińskiej Wsi) oraz Berlin. W stolicy Prus młodą Skórzewską zaciekawiły nauki przyrodnicze, które w XVIII wieku cieszyły się szczególnym zainteresowaniem amatorów. Wyrazem tej pasji generałowej jest jej księgozbiór. Na podstawie pośmiertnego inwentarza ruchomości Marianny Skórzewskiej można dokonać rekonstrukcji zawartości jej biblioteki. Generałowa posiadała klasyczne i popularne pozycje literatury pięknej, książki z zakresu historii, a także wyróżniający się zbiór dzieł z fizyki, matematyki, astronomii.

Słowa kluczowe: Marianna z Ciecierskich Skórzewska, księgozbiór Marianny z Ciecierskich Skórzewskiej, księgozbiory prywatne w XVIII wieku, księgozbiory kobiet w XVIII wieku.

Za wstęp do niniejszego tekstu może posłużyć znana grafika, frontyspis w wydaniu Ragionamenti su la pluralità de' mondi Bernarda de Fontenelle'a z 1748 roku. Jest to szkic Charles'a Natoire'a, rytowany przez Charles'a-Nicolas Cochina, przedstawiający kobietę siedzącą przy wypełnionym książkami stoliku. Dama studiuje tomy, obok nich stoi globus. Na pierwszym planie zrozpaczone putta zalewają się łzami nad porzuconymi przez niewiastę ręcznymi robótkami i szkatułką z kosztownościami. Te atrybuty, tradycyjnie łączone z kobiecym światem, nie interesują bohaterki obrazu. Podobnież porzucone pod stołem instrumenty muzyczne i paleta malarska wskazuja że dama nie celuje w artystycznych talentach. 
Pod tą ilustracją można zamieścić następujący opis:

O dwie mile od nas mieszkała młoda i ładna dama, całkiem osobliwa, jak na owe czasy. Wybrała wiedzę jako cel życia. Dom jej pełen był matematyków, pisarzy i cudzoziemców - których przywiązywała, płacąc im złotem. Wśród nich znajdowały się jednostki wybitne. Upodobania tego nabyła, kiedy sama była jeszcze ignorantką; jednak z czasem, dzięki wytrwałym wysiłkom, zdołała wznieść się na poziom otoczenia, które sobie stworzyła. Gardząc upodobaniami płci niewieściej, wybrała sobie własne, w miarę dziwaczne. Była przystojna, ale z premedytacją zaniedbywała swój wygląd zewnętrzny. Czarować chciała tylko powabem umysłu ${ }^{1}$.

Jest to fragment wspomnień Wirydianny Fiszerowej. A dotyczy Marianny z Ciecierskich Skórzewskiej (1741-1773).

\section{Marianna z Ciecierskich Skórzewska}

Marianna Ciecierska urodziła się 6 grudnia 1741 roku jako córka Józefa Ciecierskiego, cześnika podlaskiego i Anny z Malechowskich, córki Macieja, łowczego kaliskiego ${ }^{2}$ (il. 1). Niewiele wiadomo o jej wychowaniu, choć w panegiryku napisanym i wydanym przez poznańskich karmelitów bosych z okazji jej ślubu podkreślono biegłość panny młodej w językach cudzoziemskich ${ }^{3}$. Marianna w wieku czternastu lat poślubiła w Gnieźnie czterdziestosześcioletniego generała Franciszka Skórzewskiego. Na bazie dóbr wniesionych przez Mariannę w posagu Skórzewscy zbudowali

${ }^{1}$ W. Fiszerowa, Dzieje moje własne i osób postronnych. Wiązanka spraw poważnych, ciekawych i błahych, przeł. z francuskiego E. Raczyński, Warszawa 1998, s. 57-58 (oryginał w spuściźnie prywatnej).

${ }^{2}$ Marianna z Ciecierskich Skórzewska nie doczekała się biografii. Informacje biograficzne na podstawie: W. Kęder, J. Kowalkowski, Skórzewska Marianna z Ciecierskich (1741-1773), w: Polski stownik biograficzny, t. 38, Wrocław 1997-1998, s. 359-361. Por. również: A.M. Skałkowski, Hr. Skórzewska a dwór Fryderyka II, „Roczniki Historyczne”, R. X, 1934, s. 74-88; H. Moryń, O działalności Marianny Skórzewskiej, „Żnińskie Zeszyty Historyczne" 1995, nr 15/16, s. 14-22; K. Kłudkiewicz, Marianna z Ciecierskich Skórzewska i jej „czarna legenda”, w: Stynne kobiety w Rzeczypospolitej XVIII wieku, red. A. Roćko, M. Górska, Warszawa 2017, s. 167-180.

${ }^{3}$ Walor drogiej sławy Prześwietnego Drogosława... w zamienionych Sygnetach pomyślnego Maryaszu... Franciszka Skórzewskiego... z Wielmożna IMCIA Panna Maryanna Ciecierską... zważony... przez... Karmelitów Bossych Konwentu Poznańskiego... ogłoszony, Poznań 1755.

${ }^{4}$ Marianna wniosła w posagu: dobra Margonin i Szubin, kilka wsi w województwie podlaskim i płockim, domy i place w Warszawie. Franciszek Skórzewski grunty 


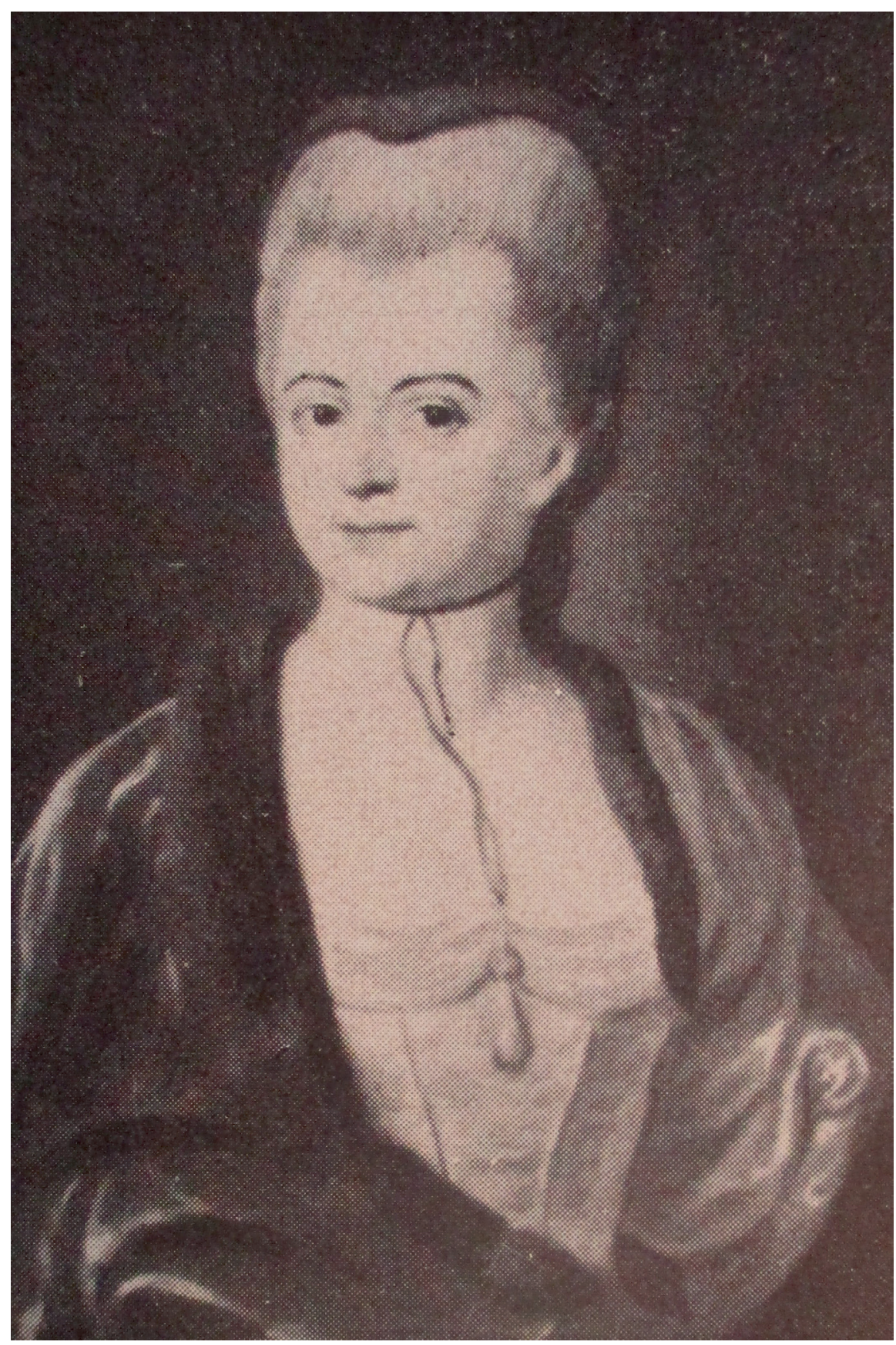

Il. 1. Portret Marianny z Ciecierskich Skórzewskiej (zaginiony) Źródło: A.M. Skałkowski, Hr. Skórzewska a dwór Fryderyka II, „Roczniki Historyczne”, R. X, 1934, s. 77. 
podstawy rodowej fortuny, która w kolejnym stuleciu była zaliczana do największych w Wielkopolsce.

Pierwsze lata małżeństwa, o których niewiele wiadomo, upłynęły na umacnianiu finansowej pozycji generałostwa i prawdopodobnie rozbudowie oraz urządzaniu okazałego pałacu w Margonińskiej Wsi. Najintensywniejszy okres w życiu Marianny przypadł jednak na lata 1765-1773.

W 1765 roku Marianna po raz pierwszy wyjechała do Berlina. Dość szybko znalazła się w najbliższym kręgu królewskiego dworu Fryderyka II, choć brakuje danych, w jaki dokładnie sposób udało jej się oczarować pruską elitę towarzyską. Sam władca w liście do Woltera 20 lutego 1767 roku pisał:

Bawi tu pewna hrabina polska; nazywa się Skórzewska; jest to swego rodzaju osobliwość. Ta kobieta ma wyraźne zamiłowanie do nauki; umie po łacinie, grec$\mathrm{ku}$, francusku, włosku i angielsku; przeczytała w każdym z tych języków wszystkich autorów klasycznych i zna ich dobrze. Benedyktyńska dusza zamieszkuje jej ciało; przytem ma dużo dowcipu, a wadzi jej tylko trudność wysławiania się w języku francuskim, którym nie włada jeszcze tak swobodnie jak swą inteligencją. Odgadniesz, czy tak zalecona dobrze była przyjętą. Potrafi rozmawiać logicznie i wnioskować, a wolna jest od płochości kobiecej. Zdumiewa to, że ukształciła się sama bez żadnej pomocy. Oto przez trzy zimy obcuje w Berlinie z ludźmi nauki, idąc za nieodpartą skłonnością która ją pociąga. Podaję ją za wzór wszystkim naszym niewiastom, którym o wiele łatwiej byłoby kształcić się, niźli tej Polce 5 .

na warszawskiej Pradze sprzedał królowi Stanisławowi Augustowi, następnie kupił majątek Niechanowo pod Gnieznem. W 1762 roku kupił prawa do sukcesji po Macieju Gembickim (bracie Anny z Gembickich Ciecierskiej, babki Marianny), w tym do dóbr Łabiszyn nad Notecią które stały się siedzibą małżonków i kolejnych pokoleń Skórzewskich. Por. W. Kęder, Skórzewski Franciszek h. Drogostaw (ok. 1709-1773), w: Polski stownik biograficzny, t. 38, Wrocław 1997-1998, s. 365-367.

${ }^{5}$ Cyt. za: A.M. Skałkowski, op.cit., s. 74 (tłum. z języka francuskiego: „Il y a ici une comtesse polonaise; elle se nomme Skorzewska; c'est une espèce phénomène. Cette femme a un amour décidé pour les lettres; elle a appris le latin, le grec, le français, l'italien et l'anglais; elle a lu tous les auteurs classiques de chaque langue, et les possède bien. L'âme d'un bénédictin réside dans son corps ; avec cela, elle a beaucoup d'esprit, et n'a contre elle que la difficulté de s'exprimer en français, langue dont l'usage ne lui est pas encore aussi familier que l'intelligence. Avec pareille recommandation, vous jugerez si elle a été bien accueillie. Elle a de la suite dans la conversation, de la liaison dans les idées, et aucune des frivolités de son sexe. Ce qu'il y a d'étonnant, c'est qu'elle s'est formée elle-même, sans aucun secours. Voilà trois hivers qu'elle passe à Berlin avec les gens de lettres, en suivant penchant irrésistible qui l'entraîne. Je prêche son exemple à toutes nos femmes, qui auraient bien une autre facilité que cette Polonaise à se former ; mais elles ne connaissent pas la félicité de ceux qui cultivent les lettres; et parce que cette volupté n'est pas vive, elles ne 
Zainteresowania naukowe generałowej potwierdzają również inne źródła. W pruskiej Akademii Nauk odczytano 26 stycznia 1769 roku jej niezachowany tekst pt. Considérations sur l'origine des Polonais ${ }^{6}$. Kilka lat później miała przesłać królowi Prus traktat z zakresu fizyki ${ }^{7}$.

Przyjaźń z osobami z otoczenia króla, jak i dobre stosunki z samym władcą Prus zaowocowały wielkimi fetami w Berlinie z okazji chrzcin pierworodnego syna Marianny, nazwanego Fryderyk na cześć królewskiego ojca chrzestnego. W latach 1768-1772 Skórzewska zaangażowała się w konfederację barską oraz mediacje pomiędzy konfederatami a Fryderykiem II. Jej dwuznaczna postawa w tym okresie, a zwłaszcza współpraca z tajnym radcą króla Prus, Franzem Balthazarem Schönbergiem von Brenckenhoffem, była różnie oceniana przez współczesnych i historyków ${ }^{8}$.

Marianna z Ciecierskich Skórzewska zmarła w Berlinie na gruźlicę w wieku 32 lat (16 listopada 1773 roku) .

\section{Księgozbiór Marianny}

25 maja 1774 roku urzędnik pruski, niejaki Hantelman, spisał majątek zmarłej Marianny Skórzewskiej ${ }^{10}$. Tytuł XIX owego inwentarza zawierał spis książek i rękopisów ${ }^{11}$.

la reconnaissent pas pour telle". CEuvres de Frédéric le Grand, t. 23: Correspondance de Frédéric II Roi de Prusse, t. 8, oprac. J.D.E. Preuss, Berlin 1853, s. 140-141.

${ }^{6}$ W. Kęder, J. Kowalkowski, op.cit., s. 360.

${ }^{7}$ R. Nowicki, Skórzewscy. Właściciele dóbr łabiszyńskich. Rola w życiu społeczno-politycznym wielkopolskiego ziemiaństwa, Toruń 2002, s. 34.

${ }^{8}$ Po 1768 roku Skórzewska grała na dwa fronty - utrzymywała przyjazne kontakty z konfederatami, a jednocześnie informowała Fryderyka o sytuacji w Polsce. Trudno ocenić jednoznacznie jej postępowanie, a tym bardziej zrekonstruować jej poglądy. W opinii Adama M. Skałkowskiego Marianna była jedynie narzędziem w rękach króla Prus, nieświadoma jego zamierzeń, zafascynowana jego osoba, wykonywała wszystkie nakazy przysyłane z Berlina (A.M. Skałkowski, op.cit., s. 81). Ryszard Nowicki podkreśla z kolei interes rodu Skórzewskich, któremu podporządkowała swoje działanie Marianna (R. Nowicki, op.cit., s. 39). Zupełnie inaczej opisywał działalność Marianny Władysław Konopczyński, który uważał, że Skórzewska miała romans z Fryderykiem II, urodziła mu syna i była zaślepiona jego osobą (W. Konopczyński, Kiedy nami rządzity kobiety, Londyn 1960, s. 43).

9 Taką datę śmierci podają Wojciech Kęder i Jacek Kowalkowski w biogramie Skórzewskiej w PSB (W. Kęder, J. Kowalkowski, op.cit., s. 360). Natomiast w inwentarzu ruchomości po śmierci Marianny jako datę jej zgonu podano 18 listopada 1773 roku (Archiwum Państwowe w Poznaniu [dalej: APP], Majątek Lubostroń, sygn. 27, k. 1).

${ }^{10}$ APP, Majatek Lubostroń, sygn. 27.

${ }^{11}$ Ibidem, k. 137-168 [dalej: inwentarz]. 
Cały inwentarz jest zszytym rękopisem zachowanym $\mathrm{w}$ dobrym stanie, o wymiarach 21 x $30 \mathrm{~cm}$. Rękopis w języku niemieckim w całości sporządził wymieniony Hantelman. Jego pismo jest raczej czytelne. W spisie biblioteki Skórzewskiej urzędnik na pierwszych stronach zapisał tytuł książki, język wydania i format. Czasem zanotował również rok wydania publikacji, rzadziej miejsce bądź wydawnictwo ${ }^{12}$. Niekiedy dodawał uwagę o stanie książki po francusku lub po niemiecku. Pod koniec spisu szczegółowość przytoczonych danych jest znacznie mniejsza. Opisy kolejnych numerów składają się tylko z dwóch, trzech pierwszych słów tytułu. Coraz mniej staranne pismo uniemożliwia w kilku przypadkach rozszyfrowanie tytułów publikacji. Porządek opisu opiera się na kryterium formatu, co może sugerować, że książki na półkach w biblioteczce Skórzewskiej były poukładane według formatów, a spisujący notował ich tytuły, przesuwając się wzdłuż półek.

Katalog zawiera 330 numery (choć nie wszystkie zostały wypełnione tytułami) oraz pięć tytułów wymienionych poza katalogiem. Na końcu spisu znajduje się również adnotacja, że nieuwzględnione książki pod numerami 334-368 to stare tomy, niekompletne i zniszczone. Wartość księgozbioru spisujący wycenił na 95 talarów. Część książek po Mariannie przejął jej syn Fryderyk Skórzewski ${ }^{13}$.

${ }^{12}$ W tekście, wskazując książki, które posiadała Marianna Skórzewska, podaję zapis bibliograficzny na podstawie inwentarza jej księgozbioru. Niekiedy są to jedynie podstawowe informacje: autor i tytuł dzieła.

${ }^{13}$ Potwierdza to spis ruchomości z pałacu w Lubostroniu, sporządzony w 1831 roku. Lubostroń był siedzibą syna Marianny. W pałacu zbudowanym na początku XIX wieku najprawdopodobniej znalazły się przedmioty odziedziczone przez Fryderyka po matce. W tytule XIII spisu uwzględniono bibliotekę Fryderyka Skórzewskiego, w której można odnaleźć tytuły książek figurujące również w spisie sporządzonym po śmierci Marianny. Por. APP, Majątek Lubostroń, sygn. 29, k. 59-106. Informacje o bibliotece lubostrońskiej - por. R. Nowicki, Kolekcja Lubostrońska, w: W stużbie ksiażki. Praca zbiorowa pod redakcja Zdzisława Kropidłowskiego ofiarowana profesorowi doktorowi habilitowanemu Franciszkowi Bonawenturze Mincerowi w siedemdziesiąta rocznice urodzin, Bydgoszcz 2002, s. 85-98. Dobra dwóch ordynackich linii rodu Skórzewskich - czerniejewskiej i lubostrońskiej na początku XX wieku znalazły się w rękach Zygmunta Skórzewskiego. Stał się on też właścicielem dwóch bibliotek zaliczanych do największych w Wielkopolsce - lubostrońskiej (liczącej w dwudziestoleciu międzywojennym 20 tys. tomów) i czerniejewskiej (liczącej wówczas 50 tys. tomów). Woluminy z bibliotek Skórzewskich można dziś odnaleźć w Bibliotece Raczyńskich i w Bibliotece Uniwersyteckiej w Poznaniu. W Bibliotece Raczyńskich nie ma książki, którą można wiązać z księgozbiorem Marianny Skórzewskiej. Por. R. Nowicki, Fragment biblioteki rodowej i ordynackiej Skórzewskich w Bibliotece Raczyńskich, „Biblioteka” 2004, nr 8, s. 49-62. Z kolei odnalezienie książek należących do Marianny Skórzewskiej w księgozbiorze Biblioteki Uniwersyteckiej 
Tabela 1. Tematyka książek w księgozbiorze Marianny z Ciecierskich Skórzewskiej

\begin{tabular}{|l|c|}
\hline \multicolumn{1}{|c|}{ Temat } & Liczba tytułów \\
\hline literatura piękna & 53 \\
\hline matematyka, fizyka, astronomia & 44 \\
\hline historia & 43 \\
\hline filozofia & 40 \\
\hline religia & 39 \\
\hline słowniki, leksykony, poradniki & 33 \\
\hline polityka & 11 \\
\hline wojskowość & 2 \\
\hline geografia & 4 \\
\hline prawo & 3 \\
\hline medycyna i farmacja & 2 \\
\hline sztuka & 2 \\
\hline muzyka & 1 \\
\hline czasopisma & 6 \\
\hline katalogi księgarskie & 2 \\
\hline
\end{tabular}

Na podstawie katalogu zidentyfikowano 285 tytułów, które w swojej bibliotece posiadała Marianna z Ciecierskich Skórzewska. Księgozbiór zdominowało sześć głównych tematycznych działów, liczących podobną liczbę tytułów (tab. 1): literatura piękna, nauki ścisłe (matematyka, fizyka, astronomia), historia, filozofia, religia oraz wydawnictwa pomocnicze (słowniki, leksykony, poradniki). Zdecydowana większość dzieł była w języku francuskim, pojedyncze egzemplarze w niemieckim, angielskim i włoskim. Spośród 20 pozycji w języku polskim większość stanowiła literatura religijna (w znacznej części dewocyjna).

w Poznaniu utrudnia brak katalogu proweniencyjnego w tej książnicy. Dotychczas na podstawie spisu biblioteki Marianny nie udało mi się zlokalizować w Bibliotece Uniwersyteckiej w Poznaniu książek Marianny Skórzewskiej. Na temat księgozbioru z Czerniejewa por. I.A. Tomczak, Księgozbiór rodziny Skórzewskich z Czerniejewa [praca magisterska pisana w Zakładzie Bibliotekoznawstwa i Dokumentalistyki Wydziału Filologii Polskiej i Klasycznej pod kierunkiem prof. Ryszarda Marciniaka], Poznań 1994. 
W zbiorze literatury pięknej wyróżniał się niemal kompletny zestaw książek autorstwa Woltera ${ }^{14}$ oraz pozycje Jeana Jacques'a Rousseau ${ }^{15}$. Skórzewska posiadała również wydania dzieł Homera ${ }^{16}$, Cycerona $^{17}$, Marka Aureliusza $^{18}$ (w tłumaczeniu francuskim), Racine' $\mathrm{a}^{19}$, Corneille'a $\mathrm{a}^{20}$, Molie$\mathrm{ra}^{21}$, a także popularne w XVIII wieku powieści Jeanne-Marie Leprince de Beaumont $^{22}$ i Anne-Louise Élie de Beaumont ${ }^{23}$. Na związki generałowej z dworem pruskim wskazywały książki odnoszące się do panowania Fryderyka II i jego otoczenia, np. album z opisem dzieł sztuki w pałacyku Sanssouci ${ }^{24}$ czy dzieła Fryderyka $\mathrm{II}^{25}$.

${ }^{14} \mathrm{~W}$ inwentarzu są to numery: 46 (Éléments de la philosophie de Newton à Londres, par M. de Voltaire à Londres 1741), 135 (Le Théâtre de M. de Voltaire, par Voltaire, 1764), 168 (Le Siècle de Louis XIV, par M. de Francheville), 190 (Euvres de Mr. Voltaire), 202 (La défense de Mon Oncle: contre ses infâmes persécuteurs, par Voltaire), 203 (La Princesse de Babylone), 204 (Contes de Guillaume Vadé), 206 (Les cuvres de Moscow).

${ }^{15} \mathrm{~W}$ inwentarzu są to numery: 59 (Emil ou de l'éducation par J.J. Rousseau, Amsterdam 1762), 64 (Histoire satirique de la vie et des ouvrages de M. Rousseau, en vers ainsi qu'en prose, par François Gacon), 93 (Supplément à la Collection complète des oeuvres de J.J. Rousseau), 94 (CEuvres diverses de Rousseau), 96 (Esprit maximes et principes de Mons. Jean Jacques), 97 (Les oeuvres de M. Rousseau), 100 (Recueil de Lettres Choisis de mons. Rousseau), 148 (Discours sur question, si le Rétablissement des Sciences et des Arts a contribué à épurer les mours), 171 (Lettres des deux amants, habitans d'une petite ville au pied des Alpes, par J. J. Rousseau), 182 (Pièces de Théâtre de Mons. Rousseau).

${ }^{16}$ L'Odyssée i L'Iliade w tłumaczeniu Anne Dacier (Madame Dacier), daty i miejsca wydania w inwentarzu nie określono (poz. 145 i 146 inwentarza).

17 Poz. 76 w inwentarzu: Tusculanes de Ciceron, traduites par messieurs Bouhier, $\mathcal{E}$ d'Olivet, de l'Academie francoise. Avec des remarques, 1739.

${ }^{18}$ Poz. 77 w inwentarzu: Réflexions de l'empereur Marc Aurèle Antonin, surnommé le philosophe, par Marc Aurèle, Dresden 1754.

${ }^{19}$ Bliżej nieokreślone Oeuvres de Racine'a (inwentarz, poz. 126), ale także komentarz do dzieł Racine'a: Commentaires sur les œuvres de Jean Racine (inwentarz, poz. 134).

${ }^{20}$ Le Théâtre de Pierre'a Corneille'a, Paris, wydanie z 1750 i 1754 roku (inwentarz, poz. 129-130).

${ }^{21}$ Bliżej nieokreślone wydanie dzieł Moliera (inwentarz, poz. 244).

${ }^{22}$ La Nouvelle Clarice, par Madame de Beaumont, 1767 (inwentarz, poz. 127).

${ }^{23}$ Bliżej nieokreślone wydanie Lettres de Marquis de Roselle (patrz inwentarz, poz. 133).

${ }^{24}$ Beschreibung von allen Gemälden und Antiquen im Schloss zu Sanssouci, Potsdam 1772 (inwentarz, poz. 90).

${ }^{25}$ Instruction Militaire de Roi de Prusse pour ses généraux (inwentarz, poz. 254) oraz Der König von Preussen Mejestat Unterricht von der Kriegs-Kunst an seine Generale, Berlin 1761 (inwentarz, poz. 314); L'esprit du chevalier Folard, tiré de ses Commentaires, Lyon 1765 (inwentarz, poz. 44). 
W zbiorze publikacji z zakresu historii dominowały historia starożytna ${ }^{26}$ i dzieła o charakterze kompendium historii świata ${ }^{27}$ lub historii poszczególnych państw ${ }^{28}$.

Skórzewska posiadała wydania dzieł klasyków filozofii (Platona ${ }^{29}$, Monteskiusza $\left.{ }^{30}\right)$, a także myślicieli, którzy wywarli wpływ na epokę oświecenia (Gottfrieda Wilhelma Leibniza ${ }^{31}$, Johna Locke'a ${ }^{32}$ i Christiana Wolffa ${ }^{33}$ ).

W bibliotece generałowej zwraca uwagę duży zestaw słowników i leksykonów, przydatnych i ułatwiających lekturę książek o tak różnorodnej tematyce jak w jej księgozbiorze. Wymienione w spisie słowniki - języka francuskiego ${ }^{34}$, francusko-angielskie ${ }^{35}$, francusko-włoskie ${ }^{36}$, francusko-niemieckie ${ }^{37}$, francusko-łacińskie ${ }^{38}$ - wskazują, że Skórzewska korzystała $\mathrm{z}$ nich podczas lektury publikacji w różnych językach, oraz dowodza, że posługiwała się głównie językiem francuskim.

${ }^{26} \mathrm{~W}$ inwentarzu pozycje: 112 (Histoire ancienne par Charles Rollin); 113 (Histoire romaine, depuis la fondation de Rome, Paris 1739); 114 (Histoire des empereurs romains); 115 (L'Histoire de Thucydide de la guerre de Pélèponese; Histoire des Empereurs romains: depuis Auguste jusqu'à Constantin); 174 (Quinte-Curce, De la vie et des Actions d'Alexandre le Grand, 1756).

${ }^{27}$ Introduction à l'Histoire Générale ex politique de l'univers par M. de Pufendorf, 1745 (inwentarz, poz. 174); bliżej nieokreślone Histoire de l'Europe (inwentarz, poz. 224 i 225) i Histoire Universelle (inwentarz, poz. 227).

${ }^{28}$ Histoire de Suède, par le Baron de Pufendorf (inwentarz, poz. 107); Sommaire de l'Histoire de France (inwentarz, poz. 220).

${ }^{29}$ Les CEuvres de Platon, Paris 1699 (inwentarz, poz. 95).

${ }^{30}$ Lettres familières de M. le président de Montesquieu (inwentarz, poz. 102); Considerazioni sopra le cause della grandezza dei Romani e della loro decadenza per il signor di Montesquieu, 1764 (inwentarz, poz. 73).

${ }^{31}$ CEuvres Philosophiques de Monsieur Leibnitz à Amsterdam et Leipzig 1765 (inwentarz, poz. 42).

32 Essai philosophique par Monsieur Locke à Amsterdam 1755 (inwentarz, poz. 41); Abrégé de l'Essai de Monsieur Locke sur l'entendement humain, en Genève 1738 (inwentarz, poz. 43).

${ }^{33}$ Cours abrégé de la philosophie wolffienne, 1743 (inwentarz, poz. 98); Cours de mathématique par M. Chretien Wolff, Paris 1747 (inwentarz, poz. 124).

${ }^{34}$ Poz. 1 w inwentarzu: Le Dictionnaire françois de Richelet.

35 Poz. 4 w inwentarzu: Dictionnaire Royal François-anglois et Anglois-françois, par Mr. A. Boyer. Poz. 28 w inwentarzu: Grammaire angloise-françoise, par Mrs. Miege et Boyer a Paris, 1765.

${ }^{36}$ Poz. $24 \mathrm{w}$ inwentarzu: Le maiètre italien, dans sa dernière perfection, à Amsterdam 1597.

${ }^{37}$ Poz. 83 w inwentarzu: Nouveau Dictionnaire du Voyageur: François-Allemand-Latin...

38 Poz. 142 w inwentarzu: Apparat royal ou Nouveau Dictionnaire Français et latin. 
Przede wszystkim jednak w bibliotece Marianny Skórzewskiej wyróżniał się zbiór książek z zakresu matematyki, fizyki i astronomii (44 tytuły). Niezbyt duża, ale bogata w najważniejsze tytuły biblioteczka poświęcona rozwijającemu się w ciągu XVIII wieku przyrodoznawstwu wyróżniała księgozbiór generałowej wśród innych zbiorów bibliofilskich Polek $^{39}$. Powstanie tego księgozbioru było wynikiem doświadczeń życiowych generałowej i lat spędzonych $w$ Berlinie. Zbiór jest też - a może przede wszystkim - odzwierciedleniem przemian na polu popularyzacji nauki w XVIII wieku.

\section{Marianna w Berlinie - tło powstania księgozbioru}

Kiedy Marianna Skórzewska pojawiła się w Berlinie, tj. w drugiej połowie lat 60. XVIII wieku, stolica Prus była miastem powoli rozwijającym się pod względem kulturalnym i naukowym. Od połowy XVIII wieku notuje się wzrost znaczenia Berlina, który z lokalnej stolicy przeobraża się na początku XIX wieku w europejską metropolię ${ }^{40}$. Rozwój ten rozpoczął się i przebiegał pod auspicjami rządzącego od 1740 roku Prusami króla Fryderyka II. Władca z dynastii Hohenzollernów, nazywany „filozofem z Sanssouci", od lat 40. XVIII wieku skupiał grono literatów, muzyków, pisarzy i filozofów, oddających się dyskusjom w jego letniej siedzibie - pałacyku Sanssouci w Poczdamie, a także dbał o rozwój stolicy swojego państwa.

Fryderykowi II nieobce były też nauki przyrodnicze. Młody książę zainteresował się fizyką pod wpływem korespondencji z Wolterem i markizą de Châtelet, zagorzałymi propagatorami idei Newtona we Francji. Z korespondencji przyszłego króla z tą francuską parą wynika, że zajmowało go zagadnienie próżni, kierunków i siły wiatrów oraz astronomia ${ }^{41}$.

${ }^{39}$ Por. B. Judkowiak, Formacja umysłowa sawantki połowy wieku (świat ksią̇̇ek i środowisko literackie Franciszki Urszuli Radziwiłłowej), w: Kultura literacka połowy XVIII wieku w Polsce. Studia i szkice, red. T. Kostkiewiczowa, Wrocław 1992, s. 147-161; H. Wolska, Księgozbiór Konstancji Sapieżyny w świetle inwentarza z 1757 roku, „Z Badań nad Księgozbiorami Historycznymi" 1976, t. 2, s. 133-154; B. Popiołek, Zainteresowania bibliofilskie Elżbiety z Lubomirskich Sieniawskiej, kasztelanowej krakowskiej, „Rocznik Naukowo-Dydaktyczny WSP w Krakowie. Prace Historyczne" 1995, t. 167, s. 45-53; S. Wójcikowa, Biblioteka Mokotowska ks. Izabelli Lubomirskiej, „Rocznik Warszawski” 1981, t. 16, s. 361-383.

${ }^{40}$ Por. E. François, Berlin im 18. Jahrhundert. Die Geburt einer Hauptstadt, w: Tableau de Berlin. Beiträge zur "Berliner Klassik” (1785-1815), red. I. d'Aprile, M. Disselkamp, C. Sedlarz, Berlin 2005, s. 7-17.

${ }^{41}$ M. Eckert, Der König und die Naturwissenschaft, w: Frederisiko. Friedrich der Grosse. Die essays [katalog wystawy w Poczdamie w 2012 roku], Berlin 2012, s. 174-185. 
Później, po objęciu władzy przez Fryderyka, w jego pałacyku Sanssouci odbywały się eksperymenty z zakresu balistyki, rachunku prawdopodobieństwa w loterii, budowy i działania kanałów i wodociagów ${ }^{42}$.

Rozwijające się w kręgu króla Prus zainteresowanie fizyka, mechanika, matematyka, astronomią czy hydrotechniką wpisywało się w oświeceniowe przemiany w pojmowaniu filozofii naturalnej, a zwłaszcza w potrzebę jej doświadczalnego badania.

Na początku XVIII wieku nastąpiła istotna przemiana w kształceniu i nauczaniu podstaw nauk przyrodniczych ${ }^{43}$. Na uniwersytetach europejskich wprowadzono zajęcia praktyczne, a w gabinetach przyrodniczych zaczęto wykonywać eksperymenty, podczas których adepci wiedzy naocznie mogli przekonać się o słuszności teoretycznych twierdzeń. W Niemczech gabinety eksperymentalne wprowadzili kolejno: Johann Christoph Sturm na uniwersytecie w Altdorf, Hermann Friedrich Teichmeyer w Jenie, Christian Wolff w Halle ${ }^{44}$. Nauki przyrodnicze w krajach niemieckich kwitły nie tylko w kręgach uniwersyteckich, ale również (a może przede wszystkim, jak twierdzą niektórzy badacze ${ }^{45}$ ) w licznie zakładanych stowarzyszeniach naukowych - akademiach nauk.

Istotna jest w tym kontekście pozycja Berlina, w którym odpowiednikiem uniwersytetu miała być ufundowana w 1700 roku Akademia Nauk (powstała pod nazwą Brandenburgische Societät der Wissenschaften). W chwili jej powołania założono, że akademia będzie się zajmować przede wszystkim naukami przyrodniczymi: astronomia, matematyka, mechaniką fizyka, botaniką i chemią. Nacisk położono na opracowanie zagadnień z wymienionych dyscyplin nie tylko w sposób teoretyczny, ale przede wszystkim $w$ obserwatoriach i laboratoriach. $Z$ akademią związani byli wybitni matematycy i fizycy XVIII-wieczni: Pierre Louis Moreau de Maupertuis, Leonhard Euler, Joseph Jérôme le Français de Lalande, Heinrich Lambert, Johann Bernoulli III oraz Johann Elert Bode ${ }^{46}$.

Kolejną cechą charakteryzującą rozwój nauki w XVIII wieku były otwarte wykłady i publiczne pokazy eksperymentów z zakresu fizyki,

42 Ibidem.

${ }^{43}$ Por. L. Brockliss, Science, the Universities, and other public spaces: Teaching Science in Europe and the Americas, w: The Cambridge History of Science, t. 4: Eighteenth-century Science, red. R. Porter, Cambridge 2003, s. 44-86.

${ }^{44}$ A. Kleinert, Mathematik und anorganische Naturwissenschaften, w: Wissenschaften im Zeitalter der Aufklärung, red. R. Vierhaus, Göttingen 1985, s. 240.

45 O. Hochadel, Öffentliche Wissenschaft: Elektrizität in der deutschen Aufklärung, Göttingen 2003, s. 37-38.

46 Por. A. Harnack, Geschichte der Königlich Preussischen Akademie der Wissenschaften zu Berlin, t. 1-3, Berlin 1900. 
które cieszyły się ogromną popularnością w całej Europie ${ }^{47}$. Od końca XVII wieku otwarte wykłady naukowe organizowano na uniwersytetach angielskich ${ }^{48}$, a następnie $\mathrm{w}$ Lejdzie za sprawą sławnego europejskiego fizyka i matematyka Willema Jacoba 's Gravesande. Jednak prawdziwym mistrzem pokazów fizycznych stał się Jean-Antoine Nollet, który od lat 40. XVIII wieku prowadził wykłady i demonstracje w Paryżu. Do niektórych swoich pokazów używał niemal 300 urządzeń, w większości jego pomysłu. Do historii przeszły jego pokazy elektryczności z 1746 roku jednego dokonał z udziałem 180 żołnierzy straży króla Ludwika XV, drugiego $\mathrm{w}$ obecności kilkuset mnichów z paryskiego klasztoru kartuzów $^{49}$. Zasłynął również demonstrowaniem elektryczności na damach z paryskiego towarzystwa. Łączące elementy pokazu teatralnego z popularnonaukowym wykładem pokazy fizyki początkowo organizowane dla wąskiego grona odbiorców (np. dla królewskiego dworu czy arystokratycznego salonu), z czasem stawały się wydarzeniami otwartymi dla szerokiej publiczności, by w drugiej połowie stulecia stać się obowiązkowym punktem towarzyskich wieczorów nie tylko w wyższych sferach społeczeństwa ${ }^{50}$.

Moda na otwarte pokazy doświadczeń z zakresu fizyki nie ominęła Niemiec, choć nie zdobyła tak licznego grona sympatyków jak we

47 Por. M.R. Lynn, Popular science and public opinion in eighteenth-century France, Manchester 2006.

48 Pierwszym naukowcem prowadzącym wykłady otwarte, połączone z pokazami eksperymentów fizycznych był John Keill z Edynburga. Za ojca popularnonaukowych wykładów dla publiczności uznaje się Williama Whistona z Cambridge, który wraz z Francisem Hauksbee, autorem popularnej rozprawy Physico-Mechanical Experiments z 1709 roku, na początku XVIII wieku oczarowali swoimi wykładami Londyn. Por. G.L'E. Turner, Teaching by demonstration. The Development of popular science, science teaching, and its apparatus in eighteenth-century Europe, w: The Art of teaching physics. The Eighteenth-century demonstration apparatus of Jean-Antoine Nollet, red. L. Pyenson, J.F. Gauvin, Quebec 2002, s. 3-4.

${ }^{49}$ Demonstracja, która przyniosła Nolletowi sławę, polegała na ustawieniu szeregu ludzi trzymających się za ręce. Pierwszy z nich dotykał metalowego pręta wystającego z naelektryzowanej butli (tzw. butelki ledejskiej), a w tym samym momencie cały szereg podskakiwał z przerażenia.

${ }^{50}$ Por. wspomnienia niemieckiej arystokratki Sophie von La Roche, która opisała w pamiętniku swój pobyt w Londynie w 1786 roku i regularny udział w fizycznych eksperymentach. Ibidem, s. 5. A także tekst w "Journal des Luxus und der Moden", w którym lekarz Christoph Wilhelm Hufeland wskazuje z ironia, że fizyka i udział w demonstracjach praw fizyki należą do dobrego tonu w towarzystwie (Ch.W. Hufeland, Einige Ideen über die neuesten Modearzneyen und Charlatanerien, "Journal des Luxus und der Moden" 1789, nr 4, s. 411-434 (tu: 411). 
Francji czy w Anglii51. Szczególną popularnością cieszyły się tu pokazy elektryczności. Od lat 40. XVIII wieku przygotowywali je: w Wittenberdze Georg Matthias Bose, w Lipsku Christian August Hausen i Johann Heinrich Winkler ${ }^{52}$, w Berlinie Christian Friedrich Ludolff. Ten ostatni zorganizował pierwsze pokazy w roku 1743 na dworze Fryderyka II, a w 1744 roku demonstrował działanie elektryczności przed zgromadzeniem członków Akademii Berlińskiej ${ }^{53}$.

Na marginesie należy dodać, że na gruncie polskim jednym z niewielu popularyzatorów nauki był ks. Józef Rogaliński, uczeń wspomnianego pioniera wykładów publicznych w Paryżu Jeana-Antoine'a Nolleta. Rogaliński po powrocie z zagranicznych studiów do Polski osiadł w Poznaniu i w 1762 roku rozpoczął pracę w tutejszym kolegium jezuickim. Wzorem swojego mistrza organizował publiczne wykłady z fizyki w stolicy Wielkopolski. W październiku 1764 roku omówił „zastosowanie praw hydrauliki na wodociągu, pompie wodnej i sikawkach", nawiązując do pożaru, który miał miejsce $\mathrm{w}$ tym roku w Poznaniu. W styczniu 1765 roku, korzystając ze zjazdu szlachty w Poznaniu, przedstawił zgromadzonym popis z objaśnieniami dotyczący hydrauliki. W czerwcu tego samego roku przeprowadził doświadczenia na skonstruowanym przez siebie wodociągu o sposobie „dochodzenia, dobywania i chędożenia kruszców i sposobie osuszania kopalni od zalewającej je wody i o środkach ku podniesieniu górnictwa krajowego" ${ }^{\prime 54}$. Z powodu braku prywatnej spuścizny Marianny Skórzewskiej trudno spekulować, czy generałowa brała udział w wykładach księdza Rogalińskiego. Na pewno w jej księgozbiorze znajdowało się najważniejsze dzieło jezuity - Doświadczenia skutków rzeczy pod zmysty podpadajacych na publicznych posiedzeniach ww. szkołach poznańskich Societatis Jesu na widok wystawione i wykładane, wydane w 1765 roku w Poznaniu ${ }^{55}$.

Podsumowując powyższy krótki zarys popularności wiedzy i nauki w XVIII wieku, warto zaznaczyć, że Marianna Skórzewska, młoda szlachcianka z prowincjonalnej Wielkopolski, znalazła się w Berlinie w chwili rozkwitu ",stulecia, w którym wiedza naukowa stała się integralną częścią

51 O. Hochadel, op.cit., s. 29-33.

52 A. Kleinert, op.cit., s. 232-233.

53 O. Hochadel, op.cit., s. 50.

${ }^{54}$ Por. W.S. Kaczmarek, Działalność Józefa Rogalińskiego na rzecz rozwoju nauk przyrodniczych w Polsce. Uwagi na marginesie ksiażki F. Chłapowskiego "Życie i praca księdza Józefa Rogalińskiego", w: F. Chłapowski, Józef Rogaliński. Uczony poznański czasów Oświecenia. Fizyk, astronom, pedagog, Poznań 2007, s. I-VIII.

55 Poz. $47 \mathrm{w}$ inwentarzu. 
zachodniej kultury"56. W stolicy Prus, podobnie jak w innych miastach europejskich, rozwijały się: zainteresowanie wiedza, popularyzatorskie nauczanie, publiczne demonstracje i amatorskie paranie się fizyką, matematyką i chemia, któremu także oddawali się król Fryderyk II i jego dworzanie.

\section{Kobieta i nauka w XVIII wieku - nauki ścisłe w księgozbiorze Skórzewskiej}

Popularyzacja nauki w XVIII wieku sprawiła, że wiedza, dotąd elitarna i dostępna dla wąskiej grupy naukowców, stała się osiągalna dla szerszego grona. W gronie tym znalazły się również kobiety. Choć ich edukacja domowa ograniczała się do podstawowych informacji o świecie, znajomości języków obcych i dobrych manier, a bramy instytucji naukowych nadal pozostały zamknięte, na rynku pojawiły się książki przeznaczone dla poszukujących wiedzy pań i zachęcające je do poszerzania horyzontów.

W 1686 roku Bernard le Bovier de Fontenelle opublikował Entretiens sur la pluralité des mondes, w którym szerokiej publiczności wyjaśnił heliocentryczny model świata i kosmologię Kartezjusza. Formuła konwersacji, w trakcie których filozof prosto objaśnia pięknej markizie arkana wie$\mathrm{dzy}$, stała się na tyle popularna, że sięgnął po nią autor najsławniejszego opracowania przeznaczonego dla pań. Francesco Algarotti w 1737 roku opublikował Il newtonianismo per le dame. W książce młody naukowiec objaśniał swojej rozmówczyni założenia teorii Newtona. „Newtonanizm dla pań", przetłumaczony szybko na kilka języków, stał się jednym z najbardziej popularnych wydań przeznaczonych dla kobiet ${ }^{57}$. Do innych prac tego typu należał m.in. opublikowany w 1715 roku leksykon dla „ciekawych i eleganckich Pań" Amaranthes'a (właśc. Gottlieb Siegmund Corvinus ${ }^{58}$ oraz niezwykle popularne dzieło, tłumaczone i wznawiane w XIX wieku - Listy do niemieckiej księżniczki Leonharda Eulera. Euler, szwajcarski matematyk, związany przez ćwierć wieku z Akademią Berlińska, został poproszony o lekcje matematyki dla Friederike Charlotte,

${ }^{56}$ Cyt. za: M.C. Jacob, The Cultural Meaning of the Scientific Revolution, New York 1988 , s. 3.

${ }^{57} \mathrm{Na}$ temat różnych sposobów popularyzacji nauki w XVIII wieku, w tym tych, których adresatem były kobiety - por. M.A. Rogers, Newtonianism for the ladies and other uneducated souls. The popularization of science in Leipzig 1687-1750, New York 2003.

58 Amaranthes, Nutzbaren, galanten und curiösen Frauenzimmer-Lexicon, Leipzig 1715. 
księżniczki Anhalt-Dessau. W kilkunastu tekstach przedstawił jej podstawy swoich odkryć matematycznych, informacje z zakresu fizyki i nauk przyrodniczych. Jego wykłady opublikowano jako Lettres à une Princesse d'Allemagne w 1768 roku.

$\mathrm{W}$ rezultacie $\mathrm{w}$ stuleciu oświeceniowym możemy odnaleźć w Europie dwie grupy kobiet, którym nauka i wiedza nie były obce. Pierwszą grupę stanowiły kobiety czynnie zaangażowane w uprawianie nauki i odnoszące na tym polu sukcesy ${ }^{59}$. Na europejskim kontynencie możemy wskazać kilka wyróżniających się nazwisk: zajmująca się fizyką i matematyką markiza du Châtelet (właśc. Gabrielle Émilie Le Tonnelier de Breteuil); chemiczka Marie-Anne Paulze, madame Lavoisier ${ }^{60}$; matematyczka i fizyczka Laura Bassi ${ }^{61}$; astronomka Maria Winkelmann ${ }^{62}$.

Drugą liczniejszą grupę stanowiły amatorki, które pod wpływem popularności nauki i wskazanych wyżej książek poszerzały swoją wiedzę w zaciszu domowym. Do tego grona należy włączyć Mariannę Skórzewską, w której bibliotece znajdował się egzemplarz francuskiego wydania Le Newtonianisme pour les dames Algarottiego z 1738 roku ${ }^{63}$. Być może jej ambicje sięgały dalej niż domowe eksperymenty. Ponoć była autorką dwóch traktatów, w tym jednego z zakresu fizyki. Nie znamy jednak szczegółów ani jej pism, ani eksperymentów, które prowadziła w Berlinie i Margonińskiej Wsi.

Jednak na podstawie omawianego spisu jej księgozbioru, a także prawdopodobnie należących do niej przyrządów, które odziedziczył jej syn Fryderyk Skórzewski, możemy stwierdzić, że generałowa należała do wcale licznego w XVIII wieku grona kobiet-amatorek dokonujących różnych eksperymentów z zakresu mechaniki i hydrotechniki.

W księgozbiorze generałowej daje się wyróżnić trzy zasadnicze grupy książek, które odzwierciedlały przemiany w naukach przyrodniczych w XVIII wieku ${ }^{64}$. Pierwszą grupę stanowiły dzieła wybitnych filozofów

${ }^{59}$ Por. R. Watts, Women in science. A social and cultural history, London-New York 2007, s. 55-78.

${ }^{60}$ Por. K. Kawashima, Emilie du Châtelet et Marie-Anne Lavoisier. Science et genre au XVIIIe siècle, Paris 2013.

${ }^{61}$ Por. M. Frize, Laura Bassi and Science in 18th Century Europe: The Extraordinary Life and Role of Italy's Pioneering Female Professor, Heidelberg-New York 2013.

${ }^{62}$ L. Schiebinger, Maria Winkelmann at the Berlin Academy. The Clash between Craft Traditions and Professional Science, w: Gendered domains. Rethinking public and private in Women's History, red. D.O. Helly, S.M. Reverby, Cornell 1992, s. 56-70.

${ }^{63}$ Inwentarz, poz. 101.

${ }^{64}$ Por. G. Lind, Physik im Lehrbuch 1700-1850. Zur Geschichte der Physik und ihrer Didaktik in Deutschland, Berlin-Heidelberg 1992, s. 14-38. 
z przełomu XVII i XVIII wieku, które wpłynęły na wyodrębnienie z filozofii przyrody nowożytnej nauki empirycznej (traktaty Gottfrieda Wilhelma Leibniza $^{65}$, Johna Locke'a ${ }^{66}$ i Christiana Wolffa $\left.{ }^{67}\right)$. Druga grupę stanowiły istotne XVIII-wieczne prace z zakresu fizyki i matematyki (Charles'a Bossueta $^{68}$, Jeana d'Alemberta ${ }^{69}$, Bernharda Nieuwentijta ${ }^{70}$, Pierre'a Van Musschenbroeka $^{71}$, Gabriela Cramera ${ }^{72}$, Alexisa Clairauta $\left.{ }^{73}\right)$. Trzecią grupę stanowiły popularne podręczniki ${ }^{74}$, teksty wykładów i poradników przeznaczonych dla amatoró $w^{75}$ oraz przydatne tablice matematyczne ${ }^{76}$, także autorstwa sławnych matematyków renesansowych - Regiomontanusa ${ }^{77}$ czy Valentinusa Otho ${ }^{78}$.

${ }^{65}$ CEuvres Philosophiques de Monsieur Leibnitz à Amsterdam et Leipzig 1765 (inwentarz, poz. 42).

${ }^{66}$ Essai philosophique par Monsieur Locke à Amsterdam 1755 (inwentarz, poz. 41); Abrégé de l'Essai de Monsieur Locke sur l'entendement humain, en Genève 1738 (inwentarz, poz. 43).

${ }^{67}$ Cours abrégé de la philosophie wolffienne, 1743 (inwentarz, poz. 98); Cours de mathématique par M. Chretien Wolff, Paris 1747 (inwentarz, poz. 124).

68 Traité élémentaire de Mécanique et de Dynamique, appliqué principalement aux mouvemens des Machines, par M. l'abbé Ch. Bossut, Charleville 1763 (inwentarz, poz. 16).

69 Traité de dynamique, par d'Alembert, à Paris 1758 (inwentarz, poz. 23); Traité sur l'équilibre par M. d'Alembert à Paris 1744 (inwentarz, poz. 40).

${ }^{70}$ Bernhardi Nieuwentijt, Analysis Infinitorum, seu curvilineorum proprietates expolygonorum natura deductae, Amsterdam 1695 (inwentarz, poz. 48).

${ }^{71}$ Essai de physique, par Mr. Pierre Van Musschenbroek, Leyden 1751 (inwentarz, poz. 49).

${ }^{72}$ Poz. $20 \mathrm{w}$ inwentarzu: Introduction à l'analyse des lignes courbes algébriques par Mr Cramer à Genève, 1750.

73 Poz. 121 (Éléments de géométrie, par Clairaut, Paris 1753) i 123 (Elemens d'Algebre par Mons. Clairaut, Paris 1746) w inwentarzu.

${ }^{74}$ Poz. 119 w inwentarzu: Anfangsgründe der angewandten Mathematik: Mechanische und Optische Wissenschaften, Kästner 1759.

${ }^{75}$ Benjamin Ursinus, [John Napier] Cursus Mathematici practici (inwentarz, poz. 34).

${ }^{76}$ Arithmetica logarithmica 1628 (inwentarz, poz. 13); Tables of Logarithmes, London 1752 (inwentarz, poz. 11); Franciscus a Schooten, Exercitationum Mathematicarum Libri Quinque (inwentarz, poz. 22); Sherwin's Mathematical Tables, London 1742 (inwentarz, poz. 45) oraz jedno z wydań Joh. Kepler, tabulae manuales logarithmicae (inwentarz, poz. 56).

77 Poz. 10 w inwentarzu: Joannis Regio Montani mathematici De triangulis planis et sphaericis, Basel.

${ }^{78}$ Poz. 12 w inwentarzu: Opus Palatinum De Triangulis. 
W księgozbiorze zainteresowanej fizyką czytelniczki nie mogło zabraknąć dzieła, które znacząco wpłynęło na rozwój dyscypliny - najważniejszego traktatu Isaaca Newtona. Skórzewska posiadała jego Principia Mathematica w pierwszym francuskim tłumaczeniu markizy de Châtelet z $1759 \mathrm{roku}^{79}$. Miała również zasady teorii Newtona wyłożone przez Woltera $\mathrm{w}$ jego sławnym dziele popularyzującym fizykę angielskiego matematyka ${ }^{80}$. Pokłosiem teorii Newtona była też znajdująca się w księgozbiorze Marianny książka La figure de la Terre Pierre'a Louisa Maupertuisa z 1738 roku $^{81}$. Autor w latach 1736-1737 kierował sławną wyprawą do Laponii, której celem było dowiedzenie teorii Newtona o spłaszczeniu kuli ziemskiej. Maupertuis dobrze znany był w Prusach, gdyż na prośbę króla Fryderyka II w latach 1744-1759 kierował pracami berlińskiej Akademii Nauk. Co istotne, Skórzewska posiadała również dzieło głównego oponenta Maupertuisa w sporze o kształt kuli ziemskiej - astronoma Jacques'a Cassiniego ${ }^{82}$. Można więc założyć, iż posiadała wiedzę o kwestiach dzielących naukowców jej czasów, zaś jej dążeniem było poznanie zdania dwóch stron aktualnych sporów.

Dobór pism z zakresu przyrodoznawstwa w bibliotece generałowej wskazuje, że nieobce jej były ważne publikacje z dziedziny (Newton, d'Alembert, Nieuwentijt, Musschenbroek, Maupertuis, Halley ${ }^{83}$ ), a także dzieła popularyzatorskie, których celem było wyłożenie nauki w sposób przejrzysty i prosty (Algarotti). Do bardzo popularnych prac z zakresu fizyki w XVIII wieku należały również Leçons de physique expérimentale Jeana-Antoine'a Nolleta, będące zapisem wspominanych wyżej pokazów i publicznych wykładów francuskiego fizyka ${ }^{84}$.

Stosunkowo duży zasób wydawnictw tablicowych, ułatwiających obliczenia logarytmów, tablic algorytmicznych itp. wskazuje z kolei, że Skórzewska dokonywała własnych eksperymentów i obliczeń.

Niezbędny był do tego gabinet fizyczny, wypełniony odpowiednimi przyrządami. O jego zawartości świadczą dwa spisy majątków

${ }^{79}$ Poz. 19 w inwentarzu: Principes mathématiques de la philosophie naturelle [traduit du latin] par Madame la marquise du Chastellet, Paris 1759.

${ }^{80}$ Poz. 46 w inwentarzu: Éléments de la philosophie de Newton à Londres, par M. de Voltaire à Londres 1741.

${ }^{81}$ La figure de la Terre, Maupertuis, Paris 1738 (inwentarz, poz. 53).

${ }^{82}$ Poz. $18 \mathrm{w}$ inwentarzu: Éléments d'Astronomie par Mons. Cassini avec le Table, Paris 1740.

${ }^{83}$ Poz. 9 w inwentarzu: Edmundi Halleii astronomi cum viveret regii Tabulae astronomicae, London 1749.

${ }^{84}$ Poz. 50 w inwentarzu: Leçons de physique expérimentale par l'Abbé Nollet, Amsterdam et Leipzig 1756. 
Skórzewskich: jeden pochodzi z 1773 roku i został sporządzony po śmierci Marianny, drugi, z 1831 roku, dokumentuje stan majątku jej syna Fryderyka Skórzewskiego.

W inwentarzu sporządzonym po śmierci Marianny Skórzewskiej w tytule XVIII spisujący wymienił dwa przyrządy: "matematyczną maszynę, która stoi przed fontanną" oraz „blaszaną maszynę elektryczną już niekompletną" ${ }^{\prime \prime}$. Spisujący majątek urzędnik najprawdopodobniej nie dysponował odpowiednią wiedzą i zasobem słownictwa do opisu przyrządów, które zobaczył w pokojach Skórzewskiej. Wskazanych maszyn nie umieścił pod kolejnymi numerami inwentarza, tylko na końcu tytułu, bez numeracji. Ogólność opisu kontrastuje też ze szczegółowością podanych cech choćby garderoby generałowej. Pierwsza ze wskazanych maszyn to prawdopodobnie urządzenie do pokazów hydromechanicznych, na co wskazuje jej ustawienie przy fontannie. Drugą musiał być rodzaj maszyny elektrostatycznej z metalowymi płytkami. Uwagi spisującego nie przykuły inne instrumenty fizyczne.

Natomiast w spisie ruchomości znajdujących się w pałacu syna Skórzewskiej w Lubostroniu $\mathrm{w} 1831$ roku ujęty został skromny zestaw instrumentów, które należy wiązać z upodobaniami jego matki. Nic nie wskazuje na to, że Fryderyk Skórzewski interesował się fizyką i matematyka, można więc założyć, że przedmioty, które inwentaryzator wymienił w spisie, a które znajdowały się w gabinecie właściciela Lubostronia, należały wcześniej do Marianny Skórzewskiej ${ }^{86}$. Znajdowały się tam: zepsuty barometr, dwa zepsute termometry, dwa mikroskopy, dwie wagi różnych rozmiarów, dwa różne zestawy instrumentów do wyrysowania perspektywy, różnego rodzaju naczynia, przez spisującego majątek określone ogólnie jako „matematyczne instrumenty" ${ }^{87}$.

O wyglądzie tych przyrządów i ich dalszych losach nic nie wiadomo. Można założyć, że gabinet fizyczny generałowej nie odbiegał wyglądem od pokojów przeznaczonych na domowe eksperymenty, jakie znajdowały się $\mathrm{w}$ różnych europejskich siedzibach arystokratycznych ${ }^{88}$. Choć nie wiadomo dokładnie, jakie eksperymenty wykonywała generałowa, możemy wyobrazić sobie ich charakter na podstawie instruktaży zawartych we wspomnianym dziele Leçons de physique expérimentale Je-

85 APP, Majątek Lubostroń, sygn. 27, k. 135.

${ }^{86}$ Ibidem, sygn. 29, k. 68.

${ }^{87}$ Ibidem.

${ }^{88}$ Por. D. Muzerelle, Le cabinet de physique du Cirey, w: Madame du Châtelet. La femme des Lumières [katalog wystawy w Bibliothèque Nationale w Paryżu], red. E. Badinter, D. Muzerelle, Paris 2003, s. 103-104 ; G.L'E. Turner, op.cit., s. 5-6. 
ana-Antoine'a Nolleta. Skórzewska posiadała to sześciotomowe opracowanie, gdzie autor drobiazgowo opisał różne doświadczenia, które można wykonać samemu. Istotnym elementem tej publikacji były ilustracje przedstawiające eksperymenty i przyrządy, jakie należy do nich dobrać. Oprócz bardzo rozbudowanych konstrukcji swojego pomysłu Nollet wskazywał bardzo proste zestawy przedmiotów - lusterka, soczewki i małe dźwignie, w które można się było zaopatrzyć wszędzie ${ }^{89}$.

\section{Podsumowanie}

Księgozbiór Marianny z Ciecierskich Skórzewskiej, którego zawartość można zrekonstruować na podstawie zachowanego inwentarza, dowodzi szczególnych zainteresowań właścicielki. Na półkach sąsiadowały tu literatura piękna i humanistyka z książkami z zakresu fizyki, matematyki i astronomii. Biblioteka jest dowodem formacji intelektualnej generałowej Skórzewskiej, a także odzwierciedleniem zwyczajów i popularnych w XVIII-wiecznej Europie amatorskich zainteresowań nauką. Katalog ukazuje również mało znaną postać Marianny Skórzewskiej: kobiety inteligentnej i ambitnej, poszukującej wiedzy, doskonalącej się w lekturze, a pod wpływem berlińskich doświadczeń oddającej się domowym eksperymentom z zakresu fizyki.

\section{Bibliografia}

Źródła

Archiwum Państwowe w Poznaniu, Majątek Lubostroń, sygn. 27, 29.

Fiszerowa W., Dzieje moje własne i osób postronnych. Wiazanka spraw poważnych, ciekawych i błahych, przeł. z francuskiego E. Raczyński, Warszawa 1998.

Walor drogiej sławy Prześwietnego Drogosława... w zamienionych Sygnetach pomyślnego Maryaszu... Franciszka Skórzewskiego... z Wielmożna IMCIA Panna Maryanna Ciecierska... zważony... przez... Karmelitów Bossych Konwentu Poznańskiego... ogłoszony, Poznań 1755.

\section{Literatura}

Brockliss L., Science, the Universities, and other public spaces: Teaching Science in Europe and the Americas, w: The Cambridge History of Science, t. 4: Eighteenth-century Science, red. R. Porter, Cambridge 2003, s. 44-86.

\footnotetext{
${ }^{89}$ G.L'E. Turner, op.cit., s. 8-9.
} 
Eckert M., Der König und die Naturwissenschaft, w: Frederisiko. Friedrich der Grosse. Die essays [katalog wystawy w Poczdamie w 2012 roku], Berlin 2012, s. $174-185$.

François E., Berlin im 18. Jahrhundert. Die Geburt einer Hauptstadt, w: Tableau de Berlin. Beiträge zur "Berliner Klassik” (1785-1815), red. I. d'Aprile, M. Disselkamp, C. Sedlarz, Berlin 2005, s. 7-17.

Frize M., Laura Bassi and Science in 18th Century Europe: The Extraordinary Life and Role of Italy's Pioneering Female Professor, Heidelberg-New York 2013.

Harnack A. von, Geschichte der Königlich Preussischen Akademie der Wissenschaften zu Berlin, t. 1-3, Berlin 1900.

Hochadel O., Öffentliche Wissenschaft: Elektrizität in der deutschen Aufklärung, Göttingen 2003.

Hufeland C.W., Einige Ideen über die neuesten Modearzneyen und Charlatanerien, "Journal des Luxus und der Moden" 1789, nr 4, s. 411-434.

Jacob M.C., The Cultural Meaning of the Scientific Revolution, New York 1988.

Judkowiak B., Formacja umysłowa sawantki połowy wieku (świat ksiażek $i$ środowisko literackie Franciszki Urszuli Radziwiłłowej), w: Kultura literacka połowy XVIII wieku w Polsce. Studia i szkice, red. T. Kostkiewiczowa, Wrocław 1992, s. $147-161$.

Kaczmarek W.S., Działalność Józefa Rogalińskiego na rzecz rozwoju nauk przyrodniczych w Polsce. Uwagi na marginesie ksiażki F. Chłapowskiego "Życie i praca księdza Józefa Rogalińskiego", w: F. Chłapowski, Józef Rogaliński. Uczony poznański czasów Oświecenia. Fizyk, astronom, pedagog, Poznań 2007, s. I-VIII.

Kawashima K., Emilie du Châtelet et Marie-Anne Lavoisier. Science et genre au XVIIIe siècle, Paris 2013.

Kęder W., Skórzewski Franciszek h. Drogosław (ok. 1709-1773), w: Polski słownik biograficzny, t. 38, Wrocław 1997-1998, s. 365-367.

Kęder W., Kowalkowski J., Skórzewska Marianna z Ciecierskich (1741-1773), w: Polski słownik biograficzny, t. 38, Wrocław 1997-1998, s. 359-361.

Kleinert A., Mathematik und anorganische Naturwissenschaften, w: Wissenschaften im Zeitalter der Aufklärung, red. R. Vierhaus, Göttingen 1985.

Konopczyński W., Kiedy nami rzadziły kobiety, Londyn 1960.

Lind G., Physik im Lehrbuch 1700-1850. Zur Geschichte der Physik und ihrer Didaktik in Deutschland, Berlin-Heidelberg 1992.

Lynn M.R., Popular science and public opinion in eighteenth-century France, Manchester 2006.

Moryń H., O działalności Marianny Skórzewskiej, „Żnińskie Zeszyty Historyczne” 1995, nr 15/16, s. 14-22.

Muzerelle D., Le cabinet de physique du Cirey, w: Madame du Châtelet. La femme des Lumières [katalog wystawy w Biblioteque Nationale w Paryżu], red. E. Badinter, D. Muzerelle, Paris 2003, s. 103-104.

Nowicki R., Fragment biblioteki rodowej i ordynackiej Skórzewskich w Bibliotece Raczyńskich, „Biblioteka” 2004, nr 8, s. 49-62.

Nowicki R., Kolekcja Lubostrońska, w: W stużbie ksiażki. Praca zbiorowa pod redakcja Zdzisława Kropidtowskiego ofiarowana profesorowi doktorowi habilitowanemu 
Franciszkowi Bonawenturze Mincerowi w siedemdziesiata rocznice urodzin, Bydgoszcz 2002, s. 85-98.

Nowicki R., Skórzewscy. Właściciele dóbr tabiszyńskich. Rola w życiu społeczno-politycznym wielkopolskiego ziemiaństwa, Toruń 2002.

CEuvres de Frédéric le Grand, t. 23: Correspondance de Frédéric II Roi de Prusse, t. 8, oprac. J.D. Erdmann Preuss, Berlin 1853.

Popiołek B., Zainteresowania bibliofilskie Elżbiety z Lubomirskich Sieniawskiej, kasztelanowej krakowskiej, „Rocznik Naukowo-Dydaktyczny WSP w Krakowie. Prace Historyczne" 1995, t. 167, s. 45-53.

Rogers M.R., Newtonianism for the ladies and other uneducated souls. The popularization of science in Leipzig 1687-1750, New York 2003.

Schiebinger L., Maria Winkelmann at the Berlin Academy. The Clash between Craft Traditions and Professional Science, w: Gendered domains. Rethinking public and private in Women's History, red. D.O. Helly, S.M. Reverby, Cornell 1992, s. 56-70.

Skałkowski A.M., Hr. Skórzewska a dwór Fryderyka II, „Roczniki Historyczne”, R. X, 1934, s. 74-88.

Tomczak I.A., Księgozbiór rodziny Skórzewskich z Czerniejewa [praca magisterska pisana w Zakładzie Bibliotekoznawstwa i Dokumentalistyki Wydziału Filologii Polskiej i Klasycznej pod kierunkiem prof. Ryszarda Marciniaka], Poznań 1994.

Turner G.L'E., Teaching by demonstration. The Development of popular science, science teaching, and its apparatus in eighteenth-century Europe, w: The Art of teaching physics. The Eighteenth-century demonstration apparatus of Jean-Antoine Nollet, red. L. Pyenson, J.F. Gauvin, Quebec 2002.

Watts R., Women in science. A social and cultural history, London-New York 2007.

Wolska H., Księgozbiór Konstancji Sapieżyny w świetle inwentarza z 1757 roku, „Z Badań nad Księgozbiorami Historycznymi" 1976, t. 2, s. 133-154.

Wójcikowa S., Biblioteka Mokotowska ks. Izabelli Lubomirskiej, „Rocznik Warszawski" 1981, t. 16, s. 361-383.

KAMILA KŁUDKIEWICZ

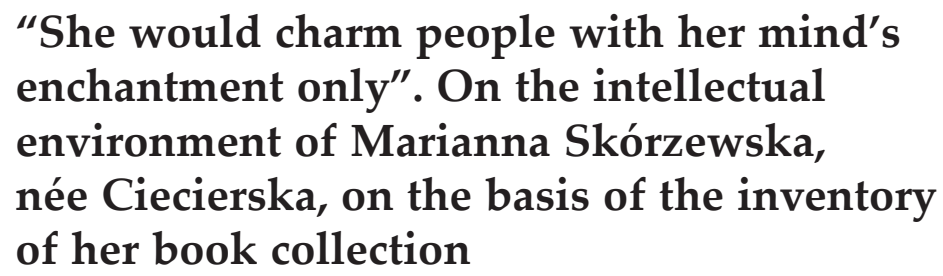

Abstract. Marianna Skórzewska, née Ciecierska (1741-1773), a wealthy noblewoman, wife of General Franciszek Skórzewski, shared her time between Greater Poland 
(palace at Margonińska Wieś) and Berlin. In the Prussian capital, young Skórzewska got interested in natural sciences that enjoyed great interest among amateurs of all kind in the eighteenth century. A manifestation of this particular passion for natural sciences was Skórzewska'a book collection. On the basis of the inventory of Skórzewska's movables, made after her death, it is possible now to reconstruct the content of her library that included not only classic and popular editions of fiction and books on history, but also a remarkable collection of scientific books on physics, mathematics and astronomy.

Key words: Marianna Skórzewska, née Ciecierska, book collection of Marianna Skórzewska, private book collections in the 18th c., book collections that belonged to women in the $18^{\text {th }} \mathrm{c}$. 